\section{DE DE GRUYTER OPEN}

Journal of Intercultural Management

Vol. 9 | No. 4 | December 2017 | pp. 77-96

DOI 10.1515/joim-2017-0022

\section{Łukasz Haromszeki}

Uniwersytet Ekonomiczny we Wrocławiu Lukasz.Haromszeki@ue.wroc.pl

\section{Piotr Jarco}

Wyższa Szkoła Zarządzania „Edukacja”

we Wrocławiu

piotr.jarco@edukacja.wroc.pl

\title{
Educational Leaders and Their Qualities from the Followers' Perspective
}

\section{ABSTRACT}

Objective: The article deals with the question of educational leadership and the understanding of that notion. That problem is relevant in the discussions on contemporary education, which is demonstrated by numerous publications concerning such areas as pedagogy, sociology of education or management. The attributes ascribed to an educational leader (personality traits, attitudes, values, etc.) are varied and arise from different experience of the authors and the applied research perspectives. The article presents the results of studies describing the characteristics of an ideal educational leader.

Methodology: The aim of the presented studies was to attempt to identify the set of traits ascribed to a contemporary educational leader and determine to what extent the respondents identify those traits as the ones they themselves possess. The studies have been based on the opinions and experience of the participants in the education system in Poland - graduates of senior secondary schools (2017). As the analysis of relevant literature on the subject does not allow one to present 
a uniform set of qualities of an ideal educational leader, the authors of the presented studies have selected 34 traits that are most frequently mentioned in scientific papers. Subsequently, during the first stage of the studies, a group of 22 experts was asked to select 17 descriptive categories (half of the presented set) that, in their view, most accurately describe an ideal educational leader. Afterwards, a sample of 108 respondents (graduates) was provided with a survey questionnaire where, using a five-point Likert scale, the participants evaluated the occurrence of a given trait/ quality in the following contexts: A pedagogue - an ideal leader; A pedagogue - a leader from the past; Self-assessment with respect to a degree of possession of the listed qualities. The studies were conducted in Google Forms technology with the randomisation of all the studied qualities of a leader for each of the questions and each of the respondents. The constructed non-random purposive sample consisted of the graduates of general education, technical and vocational senior secondary schools from cities with population exceeding 500,000 inhabitants. Men constituted $27.8 \%$ of the sample.

Findings: According to the respondents, the key traits in this case (a pedagogue - an ideal leader) included the ability to motivate others, psychological and pedagogical sensitivity and being a moral authority. The results relating to the educational leader from the past show a slightly different order of the key qualities resulting from the respondents' own experience. The first place was taken by high intellectual capabilities. It was followed by the ability to motivate others and being a moral authority. When conducting self-assessment with respect to the listed leadership qualities, the participants indicated that the qualities they possessed to the greatest degree included psychological and pedagogical sensitivity, the ability to interpret other people's expectations and the ability to plan the necessary changes. The achieved results also show that the averaged ( ) self-assessment regarding the degree of possession of all the leadership qualities in comparison to the qualities ascribed to an ideal leader is lower by $21.97 \%$. At the stage of designing the studies, it may have been expected that more significant differences would be revealed between the imagined ideal type of a leader and the self-assessment of the graduates with respect to leadership predisposition/qualities.

Value Added: In summary, the applied quantitative method of measurement allows one to confirm the accuracy of the set of leadership qualities determined on the basis of the relevant literature on the subject. According to the opinions of the graduates taking part in the study (former participants of leadership relationships), it correctly describes an educational leader. That knowledge may have practical application, especially in the conscious building of leadership in the educational environment. This is because it may be assumed that the stronger the correspondence of the set of qualities of an educational leader with the expectations of the followers, the better the chance for the creation of an effective leadership relationship.

Recommendations: The perspective of the "followers" who have their own individual experience with respect to relationships with "educational leaders" seems to be worth exploring further. The analysis of available publications on the subject in question gives grounds for posing a question to what extent the postulated image of the educational leader has any empirical foundations and to what degree it is rather a speculation or intuition of numerous authors. 
Key words: educational leadership, leadership qualities, leader, pedagogue.

JEL codes: I210 Analysis of Education

\section{Leadership and the scope of the problem}

Scientific approaches to the matter of organisational leadership date back to the 1930s. In the past eighty years researchers have tried to explain the phenomenon of leadership by analysing personality traits, behaviour and situational factors affecting a person who influences people. The most characteristic feature of the early studies of leadership was the conviction that there were internal, inborn qualities predestining selected persons to influence effectively other group members. A division described by Levinston (2007) that was proposed as part of the trait approach to leadership comprised thinking, feelings, interrelations and visible behavioural traits. Seemingly easy, the identification of specific traits proved to be impossible in practice. The failures of the trait approach brought about an increased interest in studies of human behaviour aiming to determine the patterns of behaviour of an effective leader that could subsequently be implemented e.g. in educational programmes. That approach was born from behaviourists' convictions that leadership behaviours can be learnt. Such a way of thinking opened the door to the development of management sciences and resulted in the increased popularity of the idea of leadership for anyone who would like to become a leader. Leadership educational programmes are offered by various business schools around the world. They undeniably give a chance to learn the tactics of influencing others, owing to a better understanding of the rules governing social life. However, there is no unequivocal connection between the educational process and individual successes in the area of leadership in managerial positions. That difficulty resulted in the appearance of the situational approach linking a specific leadership style to certain external factors such as the place, time and nature of a given relationship.

The experience of leadership researchers in the past 80 years has resulted in the creation of a definition of organisational leadership indicating 
its multiple scopes and dependency on the co-existence of internal and external factors in an organisation. According to the aforesaid definition, "organisational leadership can be defined as a relationship between the superior and the subordinates (or co-workers, depending on the type of leadership) aimed at achieving the intended goals - as well as visions, dreams, plans, values - based on respect and confidence in the leader's competencies and frequently on the fascination with the leader and rational or irrational commitment to the implementation of jointly created vision of growth" (Haromszeki, 2010, pp. 40-41).

According to the author's own definition adopted in this text, only a person who not only feels qualified to play the role but, most importantly, is considered as the leader by his/her followers can be called a leader. If such an approach is assumed, leadership occurs only in actual situations of influencing other people and can be studied solely from the pragmatic perspective as the explanation of the effective activity that has been completed and has measurable effects. The effectiveness of leadership, according to the Leadership Categorization Theory (Lord, Foti, \& DeVader 1984), depends on having the desired traits in certain social and cultural (situational) circumstances. The leadership categorization theory assumes that people have their own ideas as to the optimum behaviour of a leader in typical or specific leadership situations based on cognitive schemas of types of leader. In this context, the notion of leadership perception appears. There is a process of creating prototypes, storing them in memory and activating them in a specific social context. "Effective leaders are the individuals who have the attributes of a category describing a leader that meet the requirements of the situation" (Kożusznik, 2005, p. 117). R.S. Lord, R.J. Foti and C.L. DeVader (1984) have identified 27 prototypical qualities of a leader. They include, inter alia, dedication, goal-orientation, being well-informed, charisma, decisiveness, responsibility, intelligence, determination, organisation and verbal skills. Other studies emphasise such factors as dedication, intelligence, charisma, strength and sensitivity (Offermann, Kennedy, \& Wirtz, 1994). Studies carried out in the 
past two decades show that effective leaders have to be flexible and adapt their behaviour to the needs of the tasks and social requirements (Hall, J. Workman, \& Marchioro, 1998; Zaccaro, Foti, \& Kenny, 1991). In addition, R.G. Lord (1977) indicates that there is a strong correlation between leadership perception and social power. According to the theory in question, leadership is the result of an individual process of information processing and not a property of certain social groups (Kożusznik, 2005, p. 118).

Organisational leadership and leadership in education have a lot in common. Although these two environments considerably differ, the social and psychological mechanisms governing the leader-follower relationships are similar.

\section{The educational leader in light of the challenges of contemporary education}

As M. Chrabąszcz states, educational leadership is a process taking place in a group, connected with teaching and learning and requiring the maintenance of respect for the autonomy and diversity of the educational-process participants. In the relevant literature, leadership is defined through the qualities and skills of the leader as well as the attitude assumed and actions taken by the leader. Authors of articles on the subject agree that an educational leader should be optimistic, good at planning his/her actions and should take care of the relationships inside and outside the school. Important qualities include, inter alia, being a good listener, empathy, self-awareness, critical assessment of one's own beliefs, awareness of one's strengths and weaknesses, and ability to cooperate. A pedagogue in the role of the educational leader should ensure proper teaching and learning conditions by determining the goals together, inspiring others, affirming successes, promoting changes, focusing on the priorities, and monitoring and evaluating the processes taking place at school (Chrabąszcz, 2014, p. 116). Other authors believe that educational leadership itself is connected with making others capable of performing their tasks to the best of their abilities and, at the same time, with a sense 
of purpose, dignity, respect for others and satisfaction (Mazurkiewicz, 2011, p. 392). Educational leadership also means "the search for and continuous interpretation of meanings carried out with the learner" (Sayer, 1995, p. 28).

K. Lorek (2011) states that a teacher, when shaping a student's attitude to learning and ushering him/her into the world of values and moral norms (teaching and educating), influences many aspects of the student's actions and functioning: by affecting the student's emotions, self-perception and the perception of other people and the surrounding reality, attitudes in the broad sense, and assessments (including self-esteem). The author particularly emphasises the importance of the teacher's authority, which, according to the basic definition of the term, means "credibility" - one of the pillars of effective leadership. As K. Lorek mentions, from the pedagogical perspective, the definition and interpretation of the leadership phenomenon is deeply embedded in such categories as the teacher's moral authority, psychological and pedagogical maturity and sensitivity, intellect and interdisciplinary knowledge.

Elements that are crucial in creating educational leadership, according to the aforementioned authors, include charisma and authority (Śmiałek, 2010), social intelligence (Hatch, 199, p. 137) and emotional intelligence (Salovey, \& Sluyter, p. 57).

The theoreticians commenting on educational leadership refer to such values as freedom, responsibility, professionalism, self-awareness, trust and critical thinking. Factors that are mentioned most frequently include the individual qualities of pedagogues, workplace factors and the characteristics of educational programmes. On the other hand, a description of the leadership relationship specifying the elements of such a relationship that are necessary for its emergence and development in specific social and cultural circumstances can rarely be found. According to Polish researchers, the effectiveness of leaders' actions depends on the application of the socalled 7 rules proposed by Covey (2007).

The studies carried out as part of the Human Capital Balance Sheet (BKL, 2014, 2015) in a project carried out by the Polish Agency for Enterprise 
Development and the Jagiellonian University in Krakow (Kocór, 2015, p. 12) in 2010-2014 (and forecasts for the subsequent years) show that the most desired competencies, irrespective of the job position for which the candidates were sought, included the competencies listed below. They strongly correspond to the postulated qualities of a contemporary educational leader. They are:

- self-organisation skills (time-management skill, self-reliance, decision-making and initiative-taking abilities, resistance to stress and willingness to work); - job-related skills (specific competencies necessary for the performance of tasks relating to a given job);

- interpersonal skills (the ability to interact with people, communicate, cooperate in a group and solve interpersonal conflicts).

Theoretical reflections on the subject of educational leadership and the fact that the term is used with reference to the actions undertaken within educational communities were the reasons why the authors have decided to conduct studies focused on determining a coherent set of traits (prototypical qualities) of a contemporary educational leader.

\section{The assumptions and results of the authors' own studies}

The aim of the presented studies was to attempt to identify the set of traits ascribed to a contemporary educational leader and determine to what extent the respondents identify those traits as the ones they themselves possess. The studies have been based on the opinions and experience of the participants in the education system in Poland - graduates of senior secondary schools (2017). The perspective of the "followers" who have their own individual experience with respect to relationships with "educational leaders" seems to be worth exploring further. The analysis of available publications on the subject in question gives grounds for posing a question to what extent the postulated image of the educational leader 
has any empirical foundations and to what degree it is rather a speculation or intuition of numerous authors.

As the analysis of relevant literature on the subject does not allow one to present a uniform set of qualities of an ideal educational leader, the authors of the presented studies have selected 34 traits that are most frequently mentioned in scientific papers. Subsequently, during the first stage of the studies, a group of 22 experts was asked to select 17 descriptive categories (half of the presented set) that, in their view, most accurately describe an ideal educational leader. That group of experts included, inter alia, such persons as human-resource-management specialists, academic teachers from social-science fields, employees of the education authority and professionally active psychologists.

The eventually selected set of leadership traits comprised the following categories, listed in a random order: the ability to interpret other people's expectations; appropriate (adequate) self-esteem; team-building skill; high intellectual capabilities; courage in thinking and actions; being a moral authority; psychological and pedagogical sensitivity; the ability to motivate others, willingness to make changes; unconventionality; taking responsibility for others; the ability to impress others; the ability to anticipate; innovativeness; being knowledgeable about various fields; the ability to create visions of the future, and the ability to plan changes.

Afterwards, a sample of 108 respondents (graduates) was provided with a survey questionnaire where, using a five-point Likert scale, the participants evaluated the occurrence of a given trait/quality in the following contexts:

- A pedagogue - an ideal leader: an abstract category referring to the ideal of leadership in education. The respondents answered the following question: Specify to what extent a pedagogue who could be called an "educational leader" should possess a given trait.

- A pedagogue - a leader from the past: a category referring to the respondents' experience from their educational past. A pedagogue - a leader from the past in that perspective may be interpreted as the so-called significant 
other - in secondary socialization a person who has an important and lasting impact on the system of values or behaviour patterns of an individual (G.H. Mead). The respondents were asked to answer the following question: When thinking of a good/effective pedagogue - a leader, we usually remember one, the most noteworthy person that we encountered in our past. Such a person has often had a great influence on our lives. Please specify to what extent the listed traits and competencies describe the pedagogue you have in mind.

- Self-assessment with respect to a degree of possession of the listed qualities: the respondents were additionally asked to assess themselves in all the proposed categories of an ideal leader. The question was: Which of the listed qualities / skills accurately describe you? Those data serve as an interesting point of reference for the two previous research contexts.

The studies were conducted in Google Forms technology with the randomisation of all the studied qualities of a leader for each of the questions and each of the respondents. The constructed non-random purposive sample consisted of the graduates of general education, technical and vocational senior secondary schools from cities with population exceeding 500000 inhabitants. Men constituted $27.8 \%$ of the sample.

The table below presents the arithmetic means of the values of traits that the respondents ascribed to an ideal educational leader, the selected educational leader from the respondent's past and, additionally, the self-assessment of the participants in the 17 listed categories.

As predicted, all the qualities relating to an ideal educational leader were given relatively high points, within the range between 3.63 and 4.61 (minimum: 1.0; maximum: 5.0). What was important to the achievement of the goal of the studies was to determine the order of the qualities (ranks) for each of the categories. The results confirm that the selected set of qualities accurately describes the imagined, ideal educational leader. According to the respondents, the key traits in this case included the ability to motivate others (4.61), psychological and pedagogical sensitivity (4.48) and being a moral authority (4.44). 
Table 1. The assessment of the key qualities of an educational leader: arithmetic means; $1-5$ scale, N-108

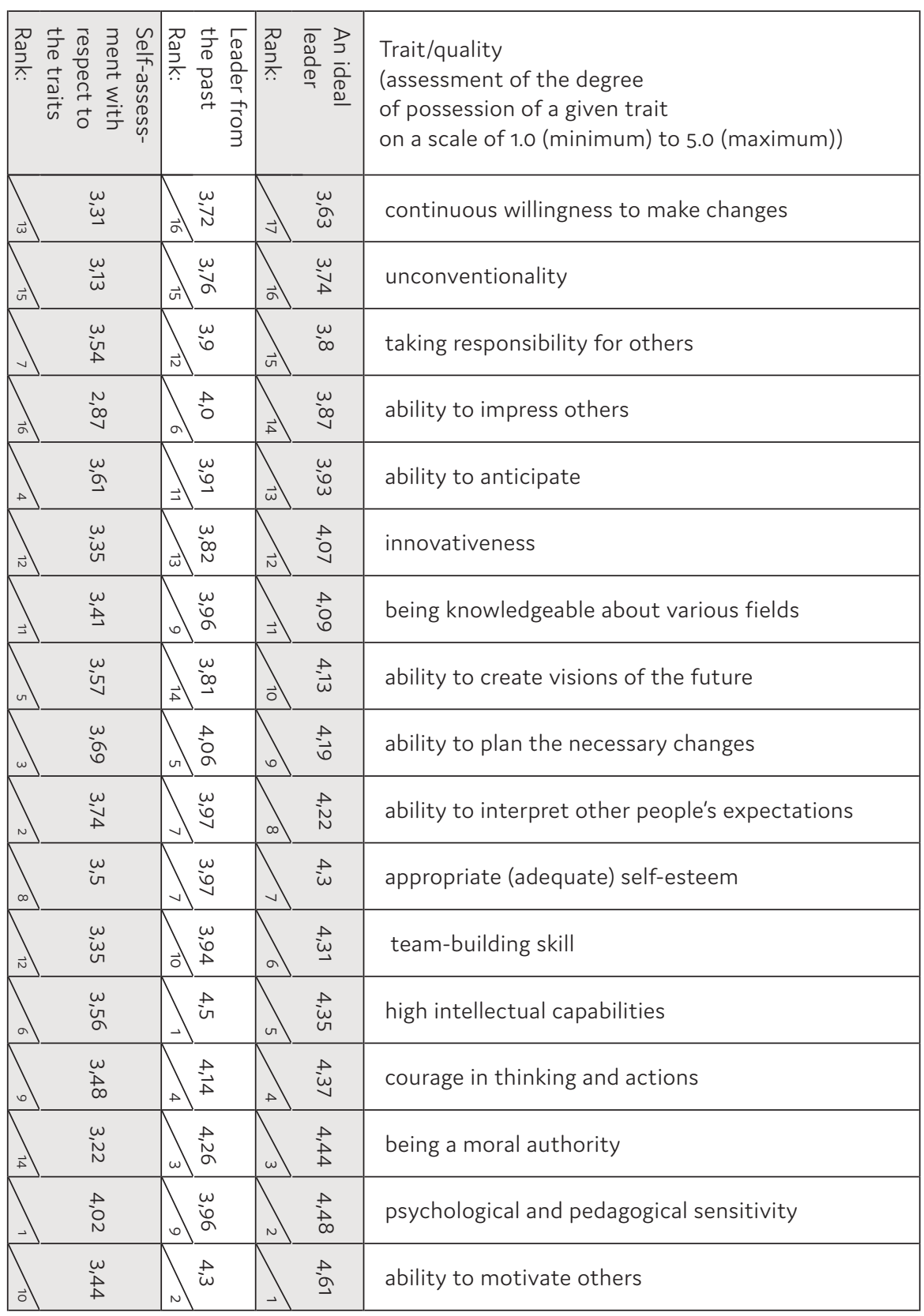

\section{Source: own studies.}


Diagram 1. The assessment of the key qualities of an educational leader: arithmetic means; 1-5 scale, $\mathrm{N}-108$

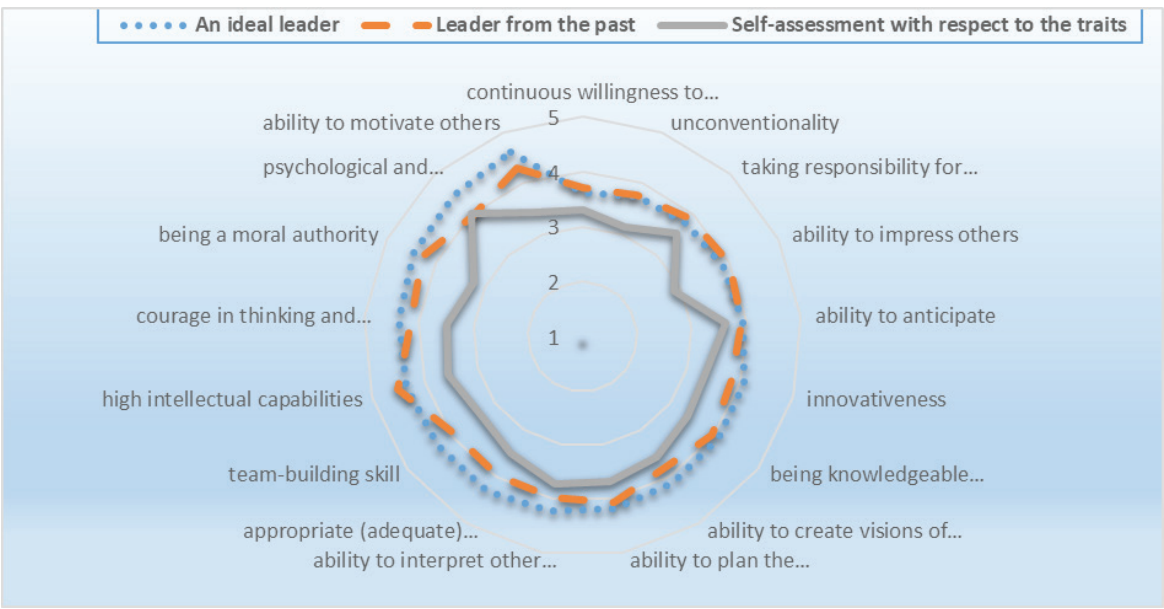

Source: own studies.

The results relating to the educational leader from the past show a slightly different order of the key qualities resulting from the respondents' own experience. The first place was taken by high intellectual capabilities (4.5). It was followed by the ability to motivate others (4.3) and being a moral authority (4.26).

When conducting self-assessment with respect to the listed leadership qualities, the participants indicated that the qualities they possessed to the greatest degree included psychological and pedagogical sensitivity (4.02), the ability to interpret other people's expectations (3.74) and the ability to plan the necessary changes (3.69).

Diagram 1 shows that there is a graphically captured discrepancy (which is relatively small and in most cases does not have any statistical significance) between the imagined ideal leader and the real leader from the past. Any noticeable differences can only be observed in such dimensions as psychological and pedagogical sensitivity, the ability to motivate others, team-building skill or appropriate (adequate) self-esteem. The remaining 
qualities of the leader from the past are equal to, or even slightly higher in intensity than, the ones indicated in the context of the ideal leader.

In the case of the third research context, i.e. the self-assessment with respect to leadership qualities, it can be noted that taking responsibility for others (3.54) and the ability to anticipate (3.61) are the qualities that the respondents claimed to possess at a relatively high level, if we assume that the point of reference was the previously indicated degree of existence of those qualities in an ideal leader (as well as a leader from the past). On the other hand, the qualities that were indicated during self-assessment as possessed to the smallest degree included the ability to impress others (2.87), unconventionality (3.12) and being a moral leader (3.22). The question remains: to what extent is such a result (regarding the aforementioned 3 qualities) determined by cultural factors and connected with specific mental images of those notions? It is likely that claiming with excessive ease (also in research circumstances) that one possesses such qualities as the ability to impress others or being an authority, especially a moral one, could be interpreted by the respondents as a sign of a lack of modesty or of conceit.

Table 2. An ideal pedagogue and the self-assessment with regard to the degree of possession of leadership qualities by the respondents - an analysis of the statistical significance of the resulting differences (Wilcoxon test)

\begin{tabular}{|c|c|c|c|c|c|c|c|c|}
\hline \multirow[b]{2}{*}{ QUALITIES } & \multicolumn{2}{|c|}{$\begin{array}{l}\text { An ideal } \\
\text { pedagogue }\end{array}$} & \multicolumn{2}{|c|}{$\begin{array}{l}\text { Self-assess- } \\
\text { ment }\end{array}$} & \multicolumn{2}{|c|}{ Difference } & \multirow{2}{*}{ 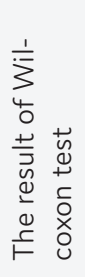 } & \multirow{2}{*}{ 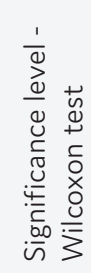 } \\
\hline & 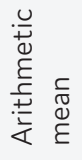 & 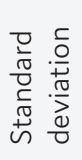 & 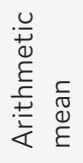 & 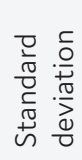 & 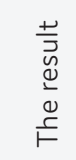 & 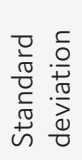 & & \\
\hline $\begin{array}{l}\text { Taking responsibility } \\
\text { for others }\end{array}$ & 3,80 & 0,97 & 3,54 & 0,84 & 0,26 & 1,24 & 2,51 & 0,012 \\
\hline Unconventionality & 3,74 & 0,85 & 3,13 & 0,77 & 0,61 & 1,08 & 5,01 & $<0,001$ \\
\hline Innovativeness & 4,07 & 0,77 & 3,35 & 0,80 & 0,72 & 0,94 & 6,17 & $<0,001$ \\
\hline
\end{tabular}




\begin{tabular}{|c|c|c|c|c|c|c|c|c|}
\hline \multirow[b]{2}{*}{ QUALITIES } & \multicolumn{2}{|c|}{$\begin{array}{l}\text { An ideal } \\
\text { pedagogue }\end{array}$} & \multicolumn{2}{|c|}{$\begin{array}{l}\text { Self-assess- } \\
\text { ment }\end{array}$} & \multicolumn{2}{|c|}{ Difference } & \multirow{2}{*}{ 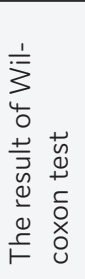 } & \multirow{2}{*}{ 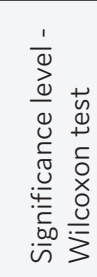 } \\
\hline & 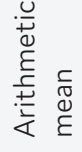 & 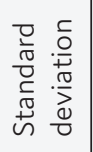 & 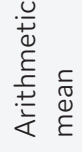 & 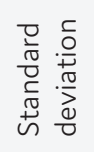 & 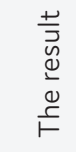 & 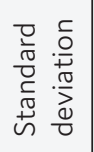 & & \\
\hline $\begin{array}{l}\text { Ability to create } \\
\text { visions of the future }\end{array}$ & 4,13 & 0,75 & 3,57 & 0,74 & 0,56 & 0,90 & 5,56 & $<0,001$ \\
\hline $\begin{array}{l}\text { Continuous will- } \\
\text { ingness to make } \\
\text { changes }\end{array}$ & 3,63 & 0,83 & 3,31 & 0,82 & 0,31 & 1,07 & 2,87 & 0,004 \\
\hline $\begin{array}{l}\text { Psychological and } \\
\text { pedagogical sensi- } \\
\text { tivity }\end{array}$ & 4,48 & 0,66 & 4,02 & 0,85 & 0,46 & 1,02 & 4,30 & $<0,001$ \\
\hline $\begin{array}{l}\text { Appropriate (ade- } \\
\text { quate) self-esteem }\end{array}$ & 4,30 & 0,76 & 3,50 & 0,79 & 0,80 & 1,13 & 5,92 & $<0,001$ \\
\hline Ability to anticipate & 3,93 & 0,82 & 3,61 & 0,81 & 0,31 & 0,98 & 3,02 & 0,003 \\
\hline $\begin{array}{l}\text { Being knowledge- } \\
\text { able about various } \\
\text { fields }\end{array}$ & 4,09 & 0,87 & 3,41 & 0,74 & 0,69 & 0,86 & 6,32 & $<0,001$ \\
\hline Team-building skill & 4,31 & 0,72 & 3,35 & 0,93 & 0,96 & 1,13 & 6,79 & $<0,001$ \\
\hline $\begin{array}{l}\text { High intellectual } \\
\text { capabilities }\end{array}$ & 4,35 & 0,67 & 3,56 & 0,66 & 0,80 & 0,85 & 6,95 & $<0,001$ \\
\hline $\begin{array}{l}\text { Ability to motivate } \\
\text { and inspire }\end{array}$ & 4,61 & 0,59 & 3,44 & 0,81 & 1,17 & 0,98 & 7,85 & $<0,001$ \\
\hline $\begin{array}{l}\text { Ability to plan the } \\
\text { necessary changes }\end{array}$ & 4,19 & 0,82 & 3,69 & 0,82 & 0,50 & 1,05 & 4,69 & $<0,001$ \\
\hline $\begin{array}{l}\text { Ability to interpret } \\
\text { other people's ex- } \\
\text { pectations }\end{array}$ & 4,22 & 0,71 & 3,74 & 0,75 & 0,48 & 0,86 & 5,09 & $<0,001$ \\
\hline $\begin{array}{l}\text { Ability to impress } \\
\text { others }\end{array}$ & 3,87 & 1,04 & 2,87 & 0,84 & 1,00 & 1,22 & 6,60 & $<0,001$ \\
\hline $\begin{array}{l}\text { Being a moral au- } \\
\text { thority }\end{array}$ & 4,44 & 0,66 & 3,22 & 0,84 & 1,22 & 0,86 & 8,09 & $<0,001$ \\
\hline $\begin{array}{l}\text { Courage in thinking } \\
\text { and actions }\end{array}$ & 4,37 & 0,78 & 3,48 & 0,88 & 0,89 & 1,04 & 6,79 & $<0,001$ \\
\hline $\bar{x}$ & 4,14 & & 3,45 & & 0,69 & & & \\
\hline
\end{tabular}

\section{Source: own studies.}

Table 2 above presents the resulting differences in the measurement of the intensity of leadership qualities for the contexts of ideal leadership and self-assessment of the respondents. An analysis with the use of the 
Wilcoxon test shows statistically significant differences for all the analysed pairs of qualities. The achieved results also show that the averaged $(\bar{x})$ self-assessment regarding the degree of possession of all the leadership qualities in comparison to the qualities ascribed to an ideal leader is lower by $21.97 \%$. At the stage of designing the studies, it may have been expected that more significant differences would be revealed between the imagined ideal type of a leader and the self-assessment of the graduates with respect to leadership predisposition/qualities.

\section{Summary}

A significant part of studies on leadership and leaders conducted so far has focused on people holding formal job positions and having real power over others. The presented survey studies based on the opinions of graduates serve as one of the possible perspectives that may be used to explore the phenomenon of leadership in education. The key conclusions that can be drawn from the presented studies are as follows:

- The set of fundamental qualities of an educational leader identified on the basis of the relevant literature on the subject (at the stage of the conceptualisation of the studies) concurs with the set of qualities of an ideal leader imagined by the graduates who were the participants in the study. According to the respondents, the key qualities of an ideal educational leader include the ability to motivate others (4.61), psychological and pedagogical sensitivity (4.48) and being a moral authority (4.44). The least important qualities from the proposed set were the ability to impress others (3.87), taking responsibility for others (3.8), unconventionality (3.74) and the willingness to make changes (3.63).

- When characterising an important leader from their own educational past, the graduates participating in the study reconstruct the image of such a person as very similar to the ideal type. The observed differences in the intensity of various qualities are small and in most cases have no statistical significance. 
- The self-assessment of the study participants with respect to the degree of possession of the leadership qualities differs from the manner in which an ideal educational leader is defined. Based on the obtained results it can be concluded that the graduates participating in the study position their leadership qualities, in the aggregate, $21.97 \%$ lower than those of the imagined ideal leader. The analysis of the differences for all the studied qualities shows statistical significance in each of the 17 cases of the qualities. Such qualities as being a moral authority, ability to motivate and inspire or ability to impress others are the ones that distinguish an ideal educational leader to the greatest extent - in relation to the assessment of the degree of possession of those qualities by the graduates themselves.

In summary, the applied quantitative method of measurement allows one to confirm the accuracy of the set of leadership qualities determined on the basis of the relevant literature on the subject. According to the opinions of the graduates taking part in the study (former participants of leadership relationships), it correctly describes an educational leader. That knowledge may have practical application, especially in the conscious building of leadership in the educational environment. This is because it may be assumed that the stronger the correspondence of the set of qualities of an educational leader with the expectations of the followers, the better the chance for the creation of an effective leadership relationship. 


\section{References}

Agrotec (2014). Analiza kwalifikacji i kompetencji kluczowych dla zwiększenia szans absolwentów na rynku pracy, RAPORT KOŃCOWY, Warszawa.

Antczak, Z. (2014). W stronę koncepcji kapitału ludzkiego. In Przyszłość zarządzania zasobami ludzkimi. Dylematy i wyzwania, Z. Antczak, S. Stanisława (ed.), Warszawa: Difin.

Bilans Kapitału Ludzkiego (BKL) (2014). Kompetencje Polaków a potrzeby polskiej gospodarki. Raport podsumowujący IV edycję badań BKL z 2013 r. (ed.) J. Górniak, PARP, Warszawa.

Chełpa, S. (2016). Kierowanie ludźmi i przywództwo. In Zarządzanie Zasobami ludzkimi, ed. T. Listwan, Warszawa: Wyd. C. H. Beck.

Chrabąszcz, N. (2014). Nauczyciel jako przywódca edukacyjny. Wolność - odpowiedzialność - skuteczność. In Edukacja jako odpowiedz. Odpowiedzialni nauczyciele w zmieniającym się świecie, red. G. Mazurkiewicz, Warszawa-Kraków: Wyd. Uniwersytetu Jagiellońskiego.

Covey, S.R. (2007). 7 nawyków skutecznego działania. translated I. Majewska-Opiełka. Poznań: Wydawnictwo Rebis.

Covey, S.R. (2011). Zasady skutecznego przywództwa. łłum. K. Pawłowski. Poznań: Wydawnictwo Rebis.

Developing Schools for Democracy in Europe (1995). ed. J. Sayer, Oxford Studies in Comparative Education, vol. 5. 
Dorczok, R. (2014). Rozwój jako centralna wartość w profesjonalnym systemie normatywnym nauczyciela - sposoby rozumienia i ich praktyczne konsekwencje. In Edukacja jako odpowiedz. Odpowiedzialni nauczyciele w zmieniającym się świecie, ed. G. Mazurkiewicz. Warszawa-Kraków: Wyd. Uniwersytetu Jagiellońskiego.

Mazurkiewicz, G. (2011). Przywództwo edukacyjne. Odpowiedzialne zarządzanie edukacją wobec wyzwań współczesności. Kraków: Wydawnictwo Uniwersytetu Jagiellońskiego.

Mazurkiewicz, G. (2015). Przywództwo edukacyjne, Zaproszenie do dialogu. Kraków: Wydawnictwo Uniwersytetu Jagiellońskiego, Ośrodek Rozwoju Edukacji Wydanie I.

Goleman, D., Boyatzis, R., McKee, A. (2002). Naturalne przywództwo. Wrocław-Warszawa: Jacek Santorski Wydawnictwo Biznesowe.

GUS, http://stat.gov.pl/obszary-tematyczne/rynek-pracy/, http://stat.gov.pl/obszary-tematyczne/ludnosc/prognoza-ludnosci/prognoza-ludnosci-na-lata-2014-2050-opracowana-2014-r-1,5.html, access: 17.12.2016.

Hall, R.J., Workman, J.W., \& Marchioro, C.A. (1998). Sex, Task and Behaioural Flexibility Effects and Leadership Perceptions. Organizational Behavior and Human Decision Processes, Vol. 74.

Haromszeki, Ł., \& Jarco, P. (2012). Create a proactive attitude by using ICT among local leaders in developing countries In: International Conference on ICT Management for Global Competitiveness and Economic Growth in Emerging Economies, ISBN: 978-83-87708-93-1, Wroclaw, pp. 194-213. 
Haromszeki, Ł. Jarco, P. (2014). Expected features and the behavior of talented leaders in the three sectors of the Polish economy in context with other Central-Eastern European Countries. Journal of Intercultural Management, red. Ł. Sułkowski, Vol. 6 , No. 4, December.

Haromszeki, Ł. (2010). Przywództwo w czasie kryzysu. In T. Listwan (ed.), Zarządzanie w sytuacjach kryzysowych podczas Euro 2012. Wydawnictwo Uniwersytetu Ekonomicznego we Wrocławiu, Wrocław.

Hatch, T. (1999). Przyjaciele, dyplomaci i przywódcy w przedszkolu: inteligencja interpersonalna w zabawie In Rozwój emocjonalny a inteligencja emocjonalna, P. Salovey, D.J. Sluyter (ed.), translated M. Karpiński, Poznań: Dom Wydawniczy REBIS.

Hay Group, (2014). Best Companies for Leadership [online], http://www.haygroup. com/ bestcompaniesforleadership/research-and-findings/about-the-research.aspx access: 25.03.2014.

Hogan, R., Curphy, G.L., \& Hogan, J. (1994). What we Know about Leadership: Effectiveness and Personality. American Psychologist, Vol. 49.

Jung, C.G. (1981). Archetypy i symbole. translated J. Prokopiuk, Warszawa: Wydawnictwo Czytelnik.

Kobyłecka, E. (2009). Nauczyciele i uczniowie gimnazjum wobec wyboru wartości. Między pewnością a zwątpieniem, Zielona Góra: Wydawnictwo Uniwersytetu Zielonogórskiego.

Kawka, T. (2012). Uelastycznienie kształtowania wynagrodzeń w organizacji. In Sukces w zarządzaniu kadrami, T1 Problemy zarządczo-ekonomiczne, ed. T. Listwan, M. Stor. Wrocław: Wyd. UE we Wrocławiu. 
Kets de Vries, M. (2008). Mistyka przywództwa. Wiodące zachowania w przedsiębiorczości. Warszawa: Wydawnictwo Studio Emka.

Kocór, M. (2015). Potrzeby zatrudnieniowe polskich pracodawców. Bilans Kapitału Ludzkiego, Warszawa, 28 April.

Kouzes, J.M., \& Posner, B.Z. (2010). Przywództwo i jego wyzwania. Kraków: Wydawnictwo Uniwersytetu Jagiellońskiego.

Koźmiński, A.K. (2004). Zarządzanie w warunkach niepewności. Warszawa.

Kożusznik, B. (2005). Wpływ społeczny w organizacji. Warszawa: Polskie Wydawnictwo Ekonomiczne, Warszawa.

Kożusznik, B. (2002). Zachowania człowieka w organizacji. Warszawa.

Levinson, H. (2007). Psychologia przywództwa, Gliwice: Wyd. Helion.

Lord, R.S., Foti, R.J., \& DeVader, C.L. (1984). A Test of Leadership Categorization Theory: Internal Structure, Information Processing and Leadership Perceptions. Organizational Behavior and Human Performance, Vol. 34.

Lord, R.G. (1977). Functional Leadership Behavior: Measurement and Relation to Social Power and Leadership Perceptions. Administrative Science Quarterly, Vol. 22.

Lorek, K. (2011). Nauczyciel (zdolny) w przestrzeni współczesnej edukacji, Materiał pomocniczy dla studentów specjalizacji i specjalności nauczycielskich. Kalisz: Wyd. Wydział Pedagogiczno-Artystyczny w Kaliszu. 
Mayer, J.D., \& Salovey, P. (1999). Czym jest inteligencja emocjonalna? In Rozwój emocjonalny a inteligencja emocjonalna, P. Salovey, D.J. Sluyter (ed.), translated M. Karpiński, Poznań: Dom Wydawniczy REBIS.

Offenmann, L.R., Kennedy, J.K., \& Wirtz, P.W. (1994). Implicit Leadership Theories: Content, Structure and Generalizability. Leadership Quarterly, No. 5.

Prentice, W.C.H. (1961). Understanding Leadership, Harvard Business Review.

Sikorski, C. (2006). Organizacje bez wodzów. Od przywództwa emocjonalnego do koordynacji demokratycznej. Warszawa: Wyd. C.H. Beck.

Suchodolski, A. (2012). Czynniki wpływające na wytyczanie kierunków rozwoju pracowników w organizacji, Sukces w zarządzaniu kadrami, T1 Problemy zarządczo-ekonomiczne, ed. T. Listwan, M. Stor), Wrocław: Wyd. UE we Wrocławiu.

Śmiałek, J. (2010). W stronę przywództwa w edukacji jutra. In Edukacja jutra. Proces kształcenia i jego uczestnicy, K. Denek et al. (ed.), Sosnowiec, Oficyna Wydawnicza Humanitas.

Wojciszke B. (2002). Człowiek wśród ludzi. Zarys psychologii społecznej. Warszawa: Wydawnictwo Naukowe Scholar.

Wyniki Narodowego Programu Foresight Polska 2020, Warszawa 2009.

Zaccaro, S.J., Foti, R.J., Kenny, D.A. (1991). Self-Monitoring and Trait-Based Variance in Leadership: an Investigation of Leader Flexibility Across Multiple Group Situations. Journal of Applied Psychology, Vol. 76. 